\title{
PEMANFAATAN RUANG PUBLIK PADA KAWASAN RUMAH TOKO DI KECAMATAN PANAKKUKANG MAKASSAR
}

\author{
Nashrah Arsyad ${ }^{1}$ \\ ${ }^{1}$ Jurusan Arsitektur Universitas Muslim Indonesia
}

\begin{abstract}
Abstrak
Ruang publik kota merupakan elemen perancangan kota yang sangat besar peranannya bagi pertumbuhan dan perkembangan kota. Keberadaannya menjadi bagian yang tak terpisahkan dari bangunan-bangunan yang ada diperkotaan. Sebagai wadah pengikat dan pernghubung antar fungsi-fungsi kawasan perkotaan, ruang publik banyak dimanfaatkan oleh masyarakat atau komunitas untuk melaksanakan kegiatan-kegiatan ekonomi, interaksi sosial atau sebatas berekreasi ringan didalamnya. Meskipun demikian, perencanaan maupun perancangan ruang publik belum mendapat perhatian yang lebih serius untuk bisa mewadahi aktifitas masyarakat kota.

Pertumbuhan ekonomi memicu pembangunan rumah toko di beberapa kota termasuk Makassar sebagai tanggapan dari kebutuhan hunian dan tuntutan ekonomi. Pembangunan kawasan rumah toko seharusnya diimbangi dengan pengadaan sarana dan prasarana sesuai tuntutan dan kebutuhannya. Namun dalam perkembangannnya, pembangunan rumah toko menjadi tidak terkendali akibat dorongan tuntutan ekonomi tersebut. Melihat fungsinya, rumah toko yang disingkat dengan "ruko" yang sejalan dengan perkembangan nilai komersil kawasan lebih menekankan pada aspek ekonomi dengan mengabaikan harmonisasi dengan lingkungan sekitarnya .

Penelitian ini bertujuan untuk mengkaji pemanfaatan ruang publik pada Kawasan Rumah Toko di Kecamatan Panakkukang Makassar melalui identifikasi kondisi eksisting ruang publik, analisis pemanfaatan ruang publik berdasarkan bentuk, jenis dan fungsi ruang terbuka publik, juga pola pemanfaatan ruang terbuka publik yang ada didalam kawasan Rumah Toko di Kecamatan Panakkukang Makassar. Keseluruhan proses analisis dalam penelitian ini menggunakan pendekatan kualitatif deskriptif dengan menggunakan teknik pengumpulan data melalui telaah dokumen, observasi lapangan secara langsung, dan wawancara.

Hasil dari penelitian ini menunjukkan bahwa pemanfaatan ruang publik pada Kawasan Rumah Toko di Kecamatan Panakkukang cukup variatif meskipun penyediaan ruang publik pada kawasan tidak dibarengi dengan perencanaan dan perancangan yang lebih optimal, proporsional dan sistemik.
\end{abstract}

Kata kunci : Kawasan rumah toko, Pemanfaatan, Ruang publik

\section{PENDAHULUAN}

Pengembangan kota pada hakekatnya ditujukan untuk memeratakan pembangunan sekaligus membuka peluang ekonomi dan pemberdayaan masyarakat secara luas. Namun pada kenyataannya pengembangan kota yang seharusnya dibarengi oleh realisasi pembangunan ruang publik sebagai respon positif para pelaksana kebijakan kota terhadap tuntutan hak-hak publik secara proporsional saat ini masih jauh dari harapan.

Dalam banyak kasus, perencanaan ruang publik yang kurang holistik, transparan, profesional, proporsional, sistemik dan sinerjik sering dituding sebagai munculnya berbagai persoalan di perkotaan yang bermuara pada proses pengadaan dan pembangunan ruang terbuka publik yang terjadi secara tidak terencana, parsial, segmental, kurang merata dan kurang tuntas.

Penyelesaian ruang terbuka publik seperti ruang luar untuk parkir, area pedestrian, ruang terbuka hijau atau taman, pada umumnya berada pada urutan paling akhir setelah suatu bangunan selesai dibangun, bahkan terkesan apa adanya. Hal ini menunjukkan bahwa pemahaman betapa pentingnya peran ruang publik masih belum begitu kental. Masalah tersebut diatas sangat mempengaruhi kualitas ruang kota secara menyeluruh.

Secara langsung nilai jual ruang publik tidak begitu menarik bagi investor, akan tetapi secara tidak langsung dapat meningkatkan kualitas ruang kota dan mengangkat nilai jual bangunan di sekitar yang dibangun atau yang akan dibangun. Sehingga sebagian pemerintah kota di Indonesia masih belum begitu memperhatikan ruang terbuka publik kota. Pengembangan kota lebih terarah pada pembangunan fisik berupa gedung-gedung fasilitas umum.

Pada sektor properti termasuk dalam pengembangan kawasan komersil "rumah toko" di Makassar, keterlibatan pengembang dalam pengadaan ruang terbuka publik belum memperlihatkan keseriusan dalam perencanaan dan perancangan ruang publik sebagai bagian integral dari unit-unit bangunan rumah toko yang ada. Keberadaan ruang publik yang ada didalam kawasan rumah toko semata-mata berfungsi sebagai ruang kosong pengikat massa bangunan belaka. Melihat fungsinya, rumah toko yang disingkat dengan "ruko" sejalan dengan perkembangan nilai 
komersil kawasan lebih menekankan pada aspek ekonomi dengan mengabaikan harmonisasi dengan lingkungan sekitarnya.

Kemajuan zaman menuntut manusia kepada tuntutan kehidupan yang lebih efektif, efisien, dan praktis. Hal ini mendorong berkembangnya ruko diseluruh penjuru dunia sebagai alternatif hunian yang dengan kesederhanaan dan kepraktisannya dapat menampung segala aktifitas dengan skala ekonomi kecil, adanya efisiensi waktu dengan adanya percampuran fungsi hunian dan kerja, dengan efisiensi lahan dan kemudahan pembangunannya.

Dengan latar belakang diatas pembangunan ruko menjadi tidak terkendali, dengan semakin menekankan aspek ekonomi tanpa memeperhatikan harmonisasi dengan lingkungan sekitar baik dalam penataan fasade, penempatan iklan , garis listplank yang akhirnya mempengaruhi dan mengaburkan identitas bangunan setempat.

\section{Landasan Teori}

\section{Peran Ruang Publik}

Menurut Carr et al. dalam E. Darmawan.(2005), ruang terbuka publik dalam suatu kawasan kota akan berperan secara baik jika mengandung unsur antara lain :

\section{a. Comfort}

Merupakan salah satu syarat mutlak keberhasilan ruang terbuka publik. Lama tinggal seseorang berada di ruang publik dapat dijadikan tolok ukur comfortable tidaknya suatu ruang terbuka publik. Dalam hal ini kenyamanan ruang terbuka publik antara lain dipengaruhi oleh : environmental comfort yang berupa perlindungan dari pengaruh alam seperti sinar matahari, angin; physical comfort yang berupa ketersediannya fasilitas penunjang yang cukup seperti tempat duduk; social and psychological comfort.

\section{b. Relaxation}

Merupakan aktifitas yang erat hubungannya dengan psychological comfort. Suasana rileks mudah dicapai jika badan dan pikiran dalam kondisi sehat dan senang. Kondisi ini dapat dibentuk dengan menghadirkan unsur-unsur alam seperti tanaman / pohon, air dengan lokasi yang terpisah atau terhindar dari kebisingan dan hiruk pikuk kendaraan disekelilingnya.

\section{c. Passive engagement}

Aktifitas ini sangat dipengaruhi oleh kondisi lingkungannya. Kegiatan pasif dapat dilakukan dengan cara duduk-duduk atau berdiri sambil melihat aktifitas yang terjadi disekelilingnya atau melihat pemandangan yang berupa taman, air mancur, patung atau karya seni lainnya.

\section{d. Active engagement}

Suatu ruang terbuka publik dikatakan berhasil jika dapat mewadahi aktifitas kontak / interaksi antar anggota masyarakat (teman, famili atau orang asing) dengan baik.

\section{e. Discovery}

Merupakan suatu proses mengelola ruang terbuka publik agar di dalamnya terjadi suatu aktifitas yang tidak monoton.

\section{Kualitas Ruang Terbuka Publik}

Perbedaan kualitas ruang kota atau kawasan dapat dipengaruhi oleh kualitas ruang publik dan tingkat sosial ekonomi masyarakat, HlldebraNl Frey (1999) dalam E. Darmawan (2005) mengkaitkan kebutuhan kota dengan kebutuhan dasar manusia dari hirarkhi Maslow sebagai berikut:

1) Pada tingkatan dasar (basic level), fasilitas kota yang disediakan adalah semua kebutuhan fisik masyarakat, antara lain: tempat tinggal dan tempat kerja, pendapatan yang memadai, pendidikan dan kursus, transportasi dan memungkinkan untuk mengadakan komunikasi dengan fasilitas-fasilitas dan pelayanan-pelayanan kota.

2) Pada tingkatan kedua, hal hal yang harus diperhatikan oleh kota adalah keselamatan (safety), keamanan (security) dan perlindungan (protection), unsur visual fungsi. Susunan dan kontrol terhadap lingkungan yang harus bebas dari polusi, kebisingan, kecelakaan, dan kriminologi.

3) Tingkatan yang ketiga adalah menciptakan lingkungan sosial yang kondusif. Suatu tempat yang penghuninya mempunyai pertumbuhan yang baik, anak-anak mereka bisa saling mengadakan sosialisasi, mereka merasa sebagai bagian dari komunitas dan merasa memiliki terbadap lingkungannya.

4) Tingkatan yang keempat, bahwa fasilitas kota harus memberikan kesan yang cocok (appropriate image), reputasi yang baik serta gengsi yang dapat menggambarkan penghuninya. Disamping dapat memberikan rasa percaya diri yang kuat, status dan martabat yang tinggi bagi mereka.

5) Pada tingkat diatasnya (kelima), fasilitas kota harus dapat memberi kesempatan penghuninya untuk berkreasi sendiri, membentuk ruang pribadi yang mengekspresikan pribadi mereka. Disamping itu secara bersama-sama mereka juga dapat menciptakan daerah dan lingkungannya sesuai dengan kebutuhan dan aspirasi mereka sendiri.

6) Tingkat yang terakhir, bahwa fasilitas kota harus berupa karya desain yang baik, sebagai tempat yang estetis, secara fisik dapat memberi kesan yang mendalam, merupakan suatu tempat budaya dan karya seni yang bermutu. Perbedaan kualitas ruang kota atau kawasan dapat dipengaruhi oleh kualitas ruang publik dan tingkat sosial masyarakat.

\section{Tinjauan Khusus Rumah Toko (RUKO)}

Ruko adalah salah satu jenis bangunan berasal dari kata rumah dan toko. Rumah yang berarti tempat berhuni dan toko yang berarti ruang untuk kegiatan usaha. Jadi ruko dapat dikatakan sebagai sebuah bangunan ;yang menggabungkan fungsi hunian dan kerja dalam satu tempat. Dengan titik 
tolak yang sederhana ini, menyebabkan ruko dalam perkembangannya menjadi sangat pesat. Disamping praktis dan murah, fungsi ruko mampu menampung kegiatan dalam skala ekonomi kecil. Sedangkan kawasan Rumah Toko adalah sebuah wilayah atau area yang didominasi atau seluruhnya terdiri atas susunan unit-unit rumah toko yang dilengkapi sarana dan prasarana penunjang kawasan. Ruko-ruko yang tersusun berderet memanjang ini membentuk satu kawasan perdagangan. Semakin berkembangnya kawasan tersebut menyebabkan nilai ekonomis kawasan tersebut meningkat, sehingga mengundang pemilik modal untuk membangun lagi Ruko-ruko dikawasan tersebut. Akibatnya, pembangunan ruko menjadi tidak terkendali, tidak memperhatikan syarat-syarat bagi fungsi hunian dan non hunian, semuanya bercampur aduk dalam kawasan tersebut. Hal ini menyebabkan terbentuknya bangunan yang tidak manusiawi, dan menghilangkan identitas lingkungannya, sehingga tanpa disadari perkembangannya kemudian menjurus pada terbentuknya satu kawasan yang kumuh.

Dengan menimbang fungsi ruko sebagai salah satu bangunan niaga, dimana faktor ekonomi sangat mempengaruhi desain, maka aspek ekonomi menjadi titik tolak dalam penataannya, yaitu :

- Penggunaan tertinggi dan terbaik : yaitu efisiensi tempat dengan penggabungan fungsi usaha dan bermukim . Pemanfaatan lahan yang maksimal dengan KDB hampir mencapai $100 \%$.

- Parkir dan Sirkulasi : sebagai pendukung dari aktifitas kegiatan perdagangan. Pertimbangan sirkulasi pejalan kaki dan sirkulasi kendaraan dengan jumlah ruang yang disediakan.

- Kenyamanan : kenyamanan fungsi hunian dan usaha yaitu kenyamanan dari pengunjung dan penghuni bangunan.

- Estetika : pertimbangan pada perancangan terhadap lingkungan dan masyarakat seperti bahan-bahan, privasi dan gaya.

- Rancangan dan citra alam : yaitu menetapkan suatu citra yang nyata bagi berbagai kelompok pemakai merupakan bagian dari kebudayaan setempat.

\section{METODOLOGI}

Metode yang digunakan untuk kepentingan dalam pengumpulan data penelitian ini adalah dengan metoda deskriptif kualitatif. Deskriptif kualitatif merupakan metode analisis dengan memaparkan keadaan objek yang dikaji dengan mengemukakan keterangan yang tidak dapat diukur secara pasti. Data-data tersebut dikumpulkan dengan cara melakukan survei lokasi, observasi, wawancara, dokumentasi, dan studi literatur.

\section{Fokus Penelitian}

Diarahkan untuk mengetahui sejauh mana pemanfaatan ruang publik pada kawasan Rumah Toko di Kecamatan Panakkukang dengan berbagai karakteristiknya, mengkaji pemanfaatan ruang publik pada Kawasan Rumah Toko di Kota Makassar melalui identifikasi kondisi eksisting ruang publik, analisis pemanfaatan ruang publik berdasarkan bentuk, jenis dan fungsi ruang terbuka publik, juga pola pemanfaatan ruang terbuka publik yang ada di dalam kawasan Rumah Toko di Kota Makassar

\section{Obyek Penelitian}

Obyek penelitian yaitu ruang publik pada kawasan rumah toko yang ada di Kecamatan Panakkukang dengan kriteria bahwa kawasan tersebut didominasi oleh bangunan rumah toko baik yang tumbuh secara alamiah maupun kawasan rumah toko yang sudah terencana dari awal. Ruang publik pada kawasan rumah toko yang menjadi obyek studi ada 3 (tiga), yaitu satu ruang publik pada kawasan yang mewakili kawasan rumah toko yang tumbuh secara alamiah yang berada disepanjang jalan Pengayoman, dan 2 (dua) ruang publik pada kawasan rumah toko yang sudah terencana dari awal, yaitu kawasan rumah toko di jalan A.P. Pettarani dan kawasan rumah toko yang terletak di jalan Pengayoman yaitu ruang publik pada kawasan Pasar Segar Makassar.

\section{PEMBAHASAN}

\section{Gambaran Umum Kawasan Rumah Toko di Kecamatan Panakkukang}

Kecamatan Panakkukang merupakan salah satu kecamatan yang berada ditengah Kota Makassar, dengan jumlah penduduk 132.479 jiwa serta kepadatan penduduknya mencapai 7.770 jiwa $/ \mathrm{km}^{2}$. Kecamatan ini juga banyak terdapat jenis usaha yang berkembang sendiri, hal ini dipengaruhi oleh adanya pusat perbelanjaan yakni Mall Panakkukang. Penyebaran pusat bisnis yang berada di Kecamatan Panakkukang awalnya dimulai dari pengadaan perumahan mewah atau real estate yang ada di Kota Makassar pada tahun 1990 yang didirikan oleh PT. Asindo Indah Griyatama Kecamatan Panakkukang. Berkembangnya kawasan ini mempengaruhi secara signifikan kawasan-kawasan lain disekitarnya yang mengakibatkan tumbuhnya kawasan-kawasan bisnis dan niaga termasuk 3 (tiga) kawasan rumah toko yang menjadi obyek studi dalam penelitian ini.

\section{Pemanfaatan Ruang Publik}

\section{a. Kawasan Kompleks Business Center Blok C. 15 di Jalan A. P. Pettarani}

Kompleks Business Center adalah salah satu kawasan Rumah Toko yang terletak di Jl. A. P. Pettarani Kecamatan Panakkukang. Posisinya yang berada di salah satu jalan utama di Kota Makassar memungkinkan aksessibilitas yang mudah ke kawasan ini.

Kawasan Ruko ini dikembangkan sebagai sebuah kawasan pusat bisnis dan niaga. Secara keseluruhan kawasan business center terdiri atas 
unit-unit rumah toko yang tersusun dan berkelompok. Setiap kelompok hanya dipisahkan oleh jalan sebagai sarana sirkulasi didalam kawasan. Pada bagian depan kawasan terdapat ruang terbuka yang cukup luas dengan material perkerasan. Tidak nampak adanya elemen-elemen desain ataupun signage pada ruang terbuka sehingga mengaburkan fungsi dari ruang terbuka didalam kawasan tersebut. Hasil survey dan pengamatan terhadap aktifitas dan pemanfaatan ruang terbuka publik diperlihatkan pada tabel 1 .

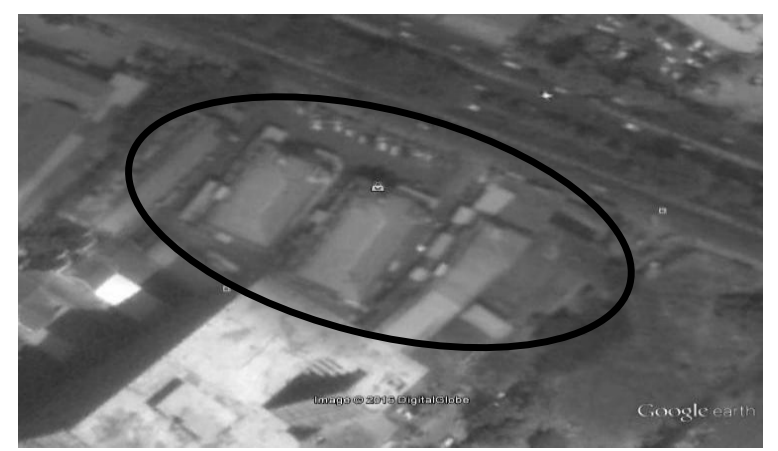

Gambar 1. Kawasan Rumah Toko Kompleks

Business Center Jl. A.P.Pettarani Makassar

Sumber : Hasil sunting dari google earth, 2016

Tabel 1. Aktifitas Pengunjung pada Ruang Terbuka Publik di Kompleks Business Center Blok C.15 Makassar.

\begin{tabular}{|l|c|c|c|}
\hline \multirow{2}{*}{ Aktifitas } & \multicolumn{3}{|c|}{ Jumlah pelaku / Waktu pengamatan } \\
\cline { 2 - 4 } & $\begin{array}{c}09.00- \\
10.00\end{array}$ & $\begin{array}{c}13.00- \\
14.00\end{array}$ & $\begin{array}{c}16.00- \\
17.00\end{array}$ \\
\hline Parkir & 22 & 18 & 16 \\
\hline Berdagang/PKL & 3 & 3 & 2 \\
\hline Berkumpul & 7 & 10 & 7 \\
\hline Berjaga & 3 & 2 & 2 \\
\hline Mengemis & 1 & 2 & 1 \\
\hline $\begin{array}{l}\text { Duduk- } \\
\text { duduk/berdiri }\end{array}$ & 4 & 2 & 6 \\
\hline Melintas & 4 & 7 & 3 \\
\hline
\end{tabular}

Sumber : Hasil olah data, 2016

Dari data yang terdapat pada tabel 1 diatas dapat diketahui bahwa pemanfaatan ruang terbuka publik Kawasan Kompleks Business Center yang paling banyak dilakukan adalah kegiatan parkir kemudian kegiatan berkumpul/berinteraksi, lalu kegiatan melintas (berjalan-jalan) dan kegiatan duduk-duduk atau berdiri. Adapun kegiatan yang sifatnya cenderung insidentil yaitu kegiatan mengemis yang hanya dilakukan oleh 1 (satu) atau 2 (dua) pelaku.

Dari hasil pengamatan memperlihatkan bahwa kegiatan-kegiatan yang dilakukan didalam area tersebut boleh dilakukan dimana saja. Tidak terlihat adanya tempat atau area untuk aktifitas tertentu sesuai fungsinya. Seperti aktifitas duduk-duduk / berkumpul dilakukan pada area parkir, sebaliknya aktifitas parkir bisa dilakukan di area mana saja yang sesuai keinginan pelaku. Pembagian area untuk kelompok-kelompok kegiatan yang berlangsung didalam ruang terbuka publik pada kawasan tidak jelas karena tidak terdapat elemen-elemen penanda zona untuk pemanfaatan area sehingga kelihatan semrawut dan tidak teratur.

\section{b. Kawasan Rumah Toko Jalan Pengayoman No. 7 - 9 (Kawasan Toko Alaska)}

Salah satu titik keramaian di jalan Pengayoman Makassar adalah kawasan bisnis dan niaga disekitar toko Alaska. Bentuk bangunan pada kawasan ini hampir seluruhnya berupa rumah toko 2 (dua) lantai atau 3 (tiga) lantai. Ruang publik yang tersedia pada kawasan sangat terbatas jika dibandingkan dengan fungsi kawasan. Bahkan terlihat ruang terbuka publik dan ruang terbuka privat sudah tidak ada batas yang memisahkan akibat fungsi dan pemanfaatan ruang yang tidak jelas. Ruang terbuka publik seperti jalan pengayoman yang berada tepat didepan toko Alaska sudah beralih fungsi menjadi area parkir pengunjung toko atau sebaliknya ruang terbuka privat yang berada didepan toko Alaska sudah menjadi area berdagang bagi PKL, berkumpul, menunggu sambil duduk-duduk, dan sebagainya.

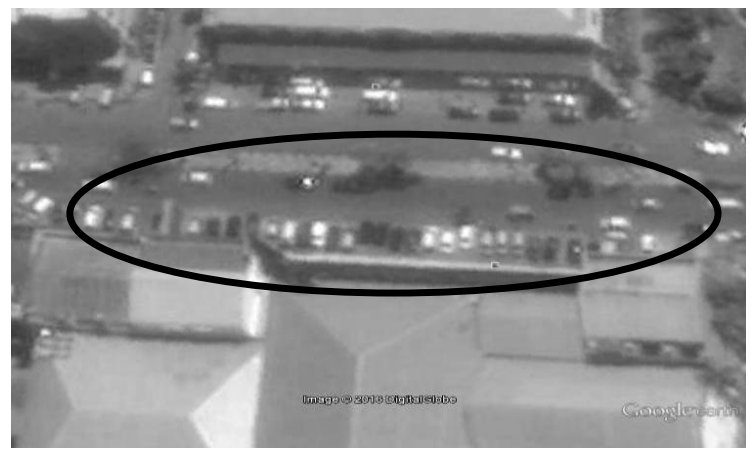

Gambar 2. Kawasan Rumah Toko jl. Pengayoman (kawasan toko Alaska) Makassar

Sumber : Hasil sunting dari google earth, 2016

Tabel 2. Aktifitas Pengunjung pada Ruang Terbuka Publik di Kawasan Rumah Toko Jl. Pengayoman

\begin{tabular}{|l|c|c|c|}
\hline \multirow{3}{*}{ Noktifitas } & \multicolumn{3}{|c|}{$\begin{array}{c}\text { Jumlah pelaku / Waktu } \\
\text { pengamatan }\end{array}$} \\
\cline { 2 - 4 } & $\begin{array}{c}09.00- \\
11.00\end{array}$ & $\begin{array}{c}13.00- \\
14.00\end{array}$ & $\begin{array}{c}16.00- \\
17.00\end{array}$ \\
\hline Parkir & 22 & 23 & 28 \\
\hline Berdagang/PKL & 3 & 3 & 4 \\
\hline Berkumpul & 2 & 3 & 6 \\
\hline Berjaga & 3 & 3 & 3 \\
\hline Mengemis & 1 & 1 & 2 \\
\hline Menunggu/duduk & 8 & 9 & 13 \\
\hline Melintas & 7 & 9 & 15 \\
\hline
\end{tabular}

Sumber : Hasil olah data, 2016

Berdasarkan hasil pengamatan, terlihat bahwa aktifitas parkir adalah aktifitas yang terbanyak dilakukan mengingat bahwa toko Alaska adalah 
salah satu toko pusat penjualan alat-alat rumah tangga yang terbesar dan banyak pengunjungnya. Keterbatasan lahan parkir toko Alaska menyebabkan kendaraan pengunjung harus memarkir pada sisi jalan hingga badan jalan Pengayoman yang menimbulkan kemacetan di sekitar kawasan tersebut. Hal ini juga terlihat pada toko-toko lain yang ada di dekat toko Alaska meskipun tidak sebanyak atau seramai toko Alaska.

\section{c. Kawasan Rumah Toko Kompleks Pasar Segar Jl. Pengayoman Makassar}

Ruang publik yang menjadi fokus pengamatan ketiga adalah ruang publik yang terletak pada kawasan yang memadukan antara rumah toko dan pasar tradisional modern (Pasar Segar). Posisi ruang publik berada di sisi paling kiri kawasan dan memanjang ke belakang dari arah pintu gerbang kawasan.

Kelebihan dari ruang publik pada kawasan ini adalah adanya koridor yang berfungsi sebagai jalur pejalan kaki serta beberapa elemen-elemen pengarah baik berupa pepohonan maupun signage pada area parkir yang membantu memperjelas fungsi dari areaarea yang ada didalam kawasan.

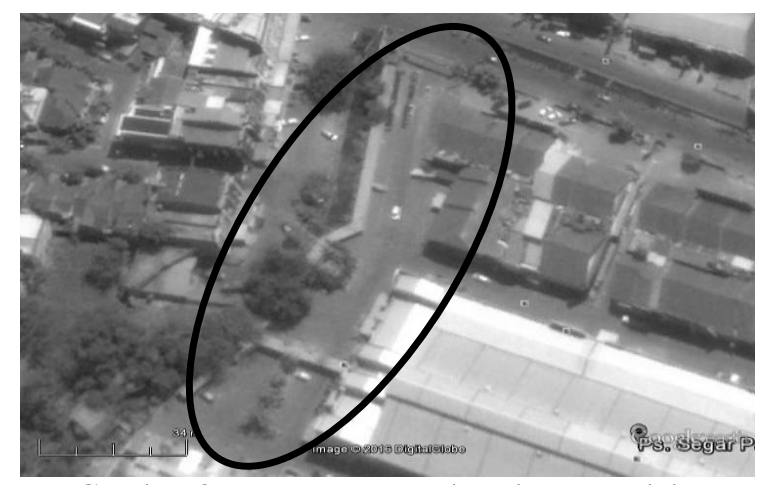

Gambar 3. Kawasan Rumah Toko Kompleks

Pasar Segar J1. Pengayoman Makassar

Sumber : Hasil sunting dari Google earth,2016

Tabel 3. Aktifitas pengunjung pada Ruang Terbuka Publik di Kawasan Pasar Segar J1. Pengayoman Makassar.

\begin{tabular}{|c|c|c|c|}
\hline \multirow{2}{*}{ Aktifitas } & \multicolumn{3}{|c|}{$\begin{array}{c}\text { Jumlah pelaku / Waktu } \\
\text { pengamatan }\end{array}$} \\
\hline & $\begin{array}{c}09.00- \\
10.00\end{array}$ & $\begin{array}{c}13.00- \\
14.00\end{array}$ & $\begin{array}{c}16.00- \\
17.00\end{array}$ \\
\hline Parkir & 16 & 27 & 31 \\
\hline Berdagang/PKL & - & - & - \\
\hline Berkumpul & - & - & - \\
\hline Berjaga & 1 & 1 & 3 \\
\hline Mengemis & - & - & 1 \\
\hline Menunggu/duduk & 2 & 6 & 3 \\
\hline Melintas & 3 & 3 & 4 \\
\hline
\end{tabular}

Sumber : Hasil olah data, 2016

Berdasarkan hasil survey dan pengamatan yang dilakukan dalam 3 (tiga) frekuensi waktu, memperlihatkan bahwa ruang terbuka publik pada kawasan rumah toko Pasar Segar pemanfaatannya lebih didominasi aktifitas parkir. Hal ini disebabkan selain karena keberadaan pasar segar sebagai pasar tradisional modern juga karena adanya pemanfaatan area ruang publik sebagai food court yang juga menarik pengunjung. Adanya food court pada ruang publik menyebabkan tidak terlihat adanya pedagang kaki lima (PKL) menjajakan dagangannya.

Secara keseluruhan pemanfaatan ruang publik di kawasan rumah toko mempunyai beberapa aspek,antara lain :

1. Sebagai wahana interaksi antar komunitas pedagang, pembeli dan pengunjung untuk berbagai tujuan, baik individu maupun kelompok.

2. Aspek aksessibilitas tanpa terkecuali yaitu bahwa ruang publik dapat dimanfaatkan oleh seluruh masyarakat sekitar.

3. Universalitas, artinya bahwa ruang publik pada kawasan rumah toko dapat mempertimbangkan berbagai kelas dan status baik masyarakat atas sampai bawah, dari anak-anak sampai dewasa, dari pria sampai wanita.

4. Ruang publik disebut bermakna manakala ada unsur kepublikan didalamnya. Jika tidak ada kepublikan maka tidak akan ada yang memanfaatkan ruang publik (lebih bersifat privat).

\section{KESIMPULAN}

Pemanfaatan ruang publik pada kawasan rumah toko di Kecamatan panakkukang Makassar cukup bervariasi sebagaimana terlihat pada ruang publik kawasan rumah toko kompleks Business Center, kawasan rumah toko no. 7-10 (Toko Alaska dan sekitarnya) di jalan Pengayoman dan ruang publik pada kawasan rumah toko Pasar Segar dan sekitarnya yang terletak di Jalan Pengayoman. Beberapa aktifitas yang teramati mulai dari akifitas parkir, berkumpul sampai pada aktifitas mengemis atau hanya sekedar melintas pada ruang publik.

Tidak adanya kejelasan fungsi dan elemenelemen ruang publik seperti signage atau pepohonan yang dapat membantu perwajahan ruang publik menyebabkan berkurangnya kualitas pemanfaatan ruang publik pada kawasan rumah toko tersebut.

Perencanaan dan perancangan kawasan rumah toko bukan hanya sekedar menyediakan ruang publik tetapi bagaimana kemudian ruang publik yang ada dapat mengakomodir aktifitas-aktifitas yang berlangsung di dalamnya.

\section{DAFTAR PUSTAKA}

[1] Budihardjo, Eko, (ed), 2009, Arsitektur Indonesia dari Perspektif Budaya, Alumni, Bandung

[2] De Chiara, Joseph dan Lee E. Koppelman, 2005, Standar Perencanaan Tapak, Erlangga, Jakarta

[3] Darmawan, Edy, 2005, Ruang Publik Dalam Pengembangan Spasial Kota, Proceeding 
Seminar Nasional Peran Ruang Publik Dalam Pengembangan Sektor Properti dan Kota, Jurusan Arsitektur Fakultas Teknik Unipersitas Diponegoro, Semarang

[4] Hakim, Rustam, 1991, Tahapan dan Proses Perancangan dalam Arsitektur Lansekap, Universitas Trisakti, Jakarta.

[5] Purnomo, Agus B, 2009, Teknik Kuantitatif Untuk Arsitektur dan Perancangan Kota, Rajawali Press, Jakarta

[6] Purwanto, Edi, 2005, Ruang Publik sebagai Setting Perkotaan, Proceeding Seminar Nasional Peran Ruang Publik Dalam Pengembangan Sektor Properti dan Kota, Jurusan Arsitektur Fakultas Teknik Unipersitas Diponegoro, Semarang

[7] Siregar, Laksmi G., 2005, Penyediaan Ruang Publik yang Me"Manusiawi"kan Kehidupan Kot Proceeding Seminar Nasional Peran Ruang Publik Dalam Pengembangan Sektor Properti dan Kota, Jurusan Arsitektur Fakultas Teknik Unipersitas Diponegoro, Semarang.

[8] Singarimbun, Masri dan Sofian Efendi, 1989, Metode Penelitian Survey, LP3ES, Jakarta

[9] Sukawi, 2005, Proceeding Seminar Nasional Peran Ruang Publik Dalam Pengembangan Sektor Properti dan Kota, Jurusan Arsitektur Fakultas Teknik Unipersitas Diponegoro, Semarang Peran Taman Kota sebagai Ruang Publik di Perkotaan, Studi kasus Taman Menetri Supeno Semarang,

[10] Sunaryo, R.G. 2002. Penataan Ruang Publik yang Memadukan Pola Aktivitas dengan Perubahan FisikKawasan, Kasus Kawasan Tambak Bayan, Babarsari, Yogyakarta. Tesis Program Magister, tidak dipublikasikan, Institut Teknologi Bandung.

[11] Yosita, Lucy, 2005, Ruang Publik di Lingkungan Perumahan Permukiman Sebuah Telaah Perbandingan antara Kondisi di Indonesia dengan Negara-Negara Maju, Proceeding Seminar Nasional Peran Ruang Publik Dalam Pengembangan Sektor Properti dan Kota, Jurusan Arsitektur Fakultas Teknik Unipersitas Diponegoro, Semarang 